guessed at, as we had only the one piece of evidence, but numerous traps spread out in other places than this alder thicket with one exception, yielded nothing. This was across the stream, perhaps 80 feet away, where the beaver had worn a path through the sod in climbing up a steep bank. About 5 feet up the bare path ceased, and under the overhanging sod were two mouse holes. One was right in the center of the path and there was no possible chance but that the beaver would spring any trap set there before the mouse got into it, but the other hole was at one side, and there I made a little shelf with my knife and set the trap which caught a Naprozapus the next morning. Further trapping at this point was fruitless, but the holes looked good, even when we left. In view of this little insight into the habits of this species I should feel rather, confident of trapping it in alder thickets along beaver streams when the fruit of the alders was ready to eat.

The beautiful colors of these mice faded rapidly, and when the last one was caught Mr. F. W. Fraser kindly gave me a painting of the fresh specimen in accurate colors. An interesting feature of this new acquaintance is the instant identification by means of the size, color, and tail. Often have I tried to study a hudsonius into an insignis in vain; but when insignis was taken, there was never a doubt, nor any need to turn to a description. I should say that insignis weighs 50 to 100 per cent more than hudsonius; the colors, similar in the museum specimen, are much more vivid, and the tail is so much heavier at the base, as to be an immediate mark of recognition.-W. E. SAUNDERS, London, Ontario.

\title{
AN INQUISITIVE PORCUPINE
}

Just at dusk on the evening of June 12, 1919, I caught sight of an adult porcupine (Erethizon dorsatum) coming along a road through heavy timber in the Penokee Range, 8 miles southwest of Mellen, Wisconsin. I remained standing still. He approached in his slow, deliberate way, absolutely unaware of my presence. The air was calm, there being no detectable breeze. At a distance of about 20 feet from me the animal stopped, looked up and around in different directions, and sniffed the air. He evidently was either rather suspicious or detected the odor of food. But he remained there only a second or two, then continued to within 15 feet, again stopped, looked directly at me, and sniffed for nearly 2 minutes, his nose in the air toward me all the while. Meantime I withstood scores of biting mosquitoes and remained perfectly silent. After "sizing up" the situation, so to speak, the porcupine changed his course an angle of 45 degrees and came directly toward me. I remained silent until he began gnawing my leather putees, when I thought it time to protest, so $I$ made a slight movement, and "porkie" scampered away and hid among the logs and brush by the roadside.-HARtLeY H. T. JACKSON, U. S. Biological Survey, Washington, D. C.

\section{GRAYSQUIRRELS AND NUTS}

At the National Zoological Park in Washington on January 23 last, I saw a graysquirrel burying a nut. It is commonly supposed that this instinct is active only in autumn. Can any one give observations to show that it is operative the 
year round when food is sufficiently plentiful?-ERNest THompson SEToN, Greenwich, Conn.

\section{FORMER RANGE OF MOUNTAIN SHEEP IN NORTHERN CALIFORNIA}

Recent references to the occurrence of mountain sheep in northern California appear to be restricted to Mount Shasta and the adjacent Sheep Rock, a locality only a few miles north of the great mountain. The present Sheep Rock however is very different from the Sheep Rock of the early gold-seekers. The latter, as shown by George Gibbs in his Journal and accompanying map of the McKee Expedition of 1851, was situated on the west side of Scott Mountains, a range to the west of Shasta Valley, which it separates from Scott Valley. The Sheep Rock of 1851 is a prominent landmark as seen from Scott Valley, and is now known both locally and on the maps of the Geological Survey as Skookum Rock. It was inhabited by Sheep in Gibbs' time--how much later we do not know.

The Shaste Indians tell me that sheep formerly occurred on Goose Nest Mountain and on Bogus Mountain north of Goose Nest Mountain, and also in the Siskiyous, but just how far west they ranged in the Siskiyous I have not been able to ascertain. In $1888 \mathrm{I}$ saw in a hardware store in Portland, Oregon, a mounted ram of large size killed in the Siskiyous by the proprietor of the store.

It would be interesting to know whether the big horn of these elevated mountains-Mount Shasta, Scott Mountains, Goose Nest Mountain, Bogus Mountain, and the Siskiyous-was the same species as the one formerly inhabiting the Modok Lava Beds in the northeastern corner of California.-C. Hart Merriam, Washington, D. C.

TWO MAMMALS NEW FOR OHIO

On February 2, 1921, Mr. Franklin Grothaus, a young farmer of my parish; brought me a fine of of Mustela cicognani. For years the state of Ohio has been searched for this species, but the fact that the closest point to Ohio where it had been taken was in Pennsylvania, about 600 miles from here, and in Michigan, about 500 miles to the north, made it unlikely that it ever would be found. It is with pleasure that $\mathrm{I}$ record this new species for the state of Ohio. Measurements: length, $268 \mathrm{~mm}$; tail, $67 \mathrm{~mm}$.; h. f., $30 \mathrm{~mm}$. The specimen is now in my collection.

The other species new for Ohio, one that has been diligently looked for, as all the old records turned out to be something else, is Microtus ochrogaster, of which I have 3 specimens up to date, all taken by Mr. Hy. Ruese, a farmer of my parish living in Shelby County, Ohio, $2 \frac{1}{2}$ miles east of New Bremen. The first one, a $q$ taken February 15, 1921, measured: length, $131 \mathrm{~mm}$.; tail, $21 \mathrm{~mm}$. ; h. f., $17.5 \mathrm{~mm}$; mamma 6, foetuses 4. The second one, taken February 22, 1921, a 8 , measured: length, $126 \mathrm{~mm}$; tail, $20 \mathrm{~mm}$; h. f., $17 \mathrm{~mm}$. Four weeks of trapping did not yield any results till on April 5 another $q$ was caught, measuring $130 \mathrm{~mm}$. in length; tail, $19 \mathrm{~mm}$; h. f., $17 \mathrm{~mm}$; mammæ 6, foetuses 0 . Thus it seems to be that the species is very rare here and probably reaches its easternmost point of distribution.-W. F. Henninger, New Bremen, Ohio. 